\title{
Variability and heterogeneity of humus forms at stand level: Comparison between pure beech and mixed beech-hornbeam forest
}

\author{
Michaël AuberT*, Pierre Margerie, Aude ERnoult, Thibaud Decä̈ns, Fabrice Bureau \\ Groupe de recherche ECODIV, UPRES-EA 1293, Faculté des Sciences et des Techniques, Université de Rouen, \\ 76821 Mont-Saint-Aignan Cedex, France
}

(Received 17 January 2005; accepted 24 August 2005)

\begin{abstract}
We investigate the influence of tree canopy composition on humus form variability and heterogeneity by comparing a pure beech stand and a mixed beech-hornbeam one (70\% beech and 30\% hornbeam). Macro-morphological humus form descriptors were recorded using a spatially explicit sample design at stand level. Leaf litter composition and light intensity accounting for stand management as well as bulk density for harvesting practices (soil compaction) were also recorded. A multiple correspondence analysis (MCA) and geostatistics were used to assess humus form variability and heterogeneity, as well as the spatial correlation between stand characteristics and humus forms. Humus form variability and activity were greater under the mixed stand than under the pure one. Geostatistics revealed that humus form patchiness was greater under the mixed stand than under the pure one and the improvement in decomposition processes seemed to be confined to spatial distribution of hornbeam litterfall. From a practical viewpoint, these results could provide ideas on the way of mixing tree species at stand level. We assume that with a given percentage of mull-forming tree species, a dispersed tree mixture provides a more extensive improvement than a clumped mixture.
\end{abstract}

humus form / pure stand / mixed stand / geostatistics / spatial pattern / heterogeneity / Fagus sylvatica / Carpinus betulus

Résumé - Variabilité et hétérogénéité des formes d'humus à l'échelle du peuplement : comparaison entre peuplement pur de hêtre et forêt mélangée hêtre-charme. Nous avons étudié l'influence de la composition d'un peuplement sur la variabilité qualitative et l'hétérogénéité spatiale des formes d'humus en comparant un peuplement pur de hêtre et un peuplement mélangé (70\% hêtre - 30\% charme). Les caractéristiques macro-morphologiques des formes d'humus ainsi que la composition spécifique de la litière, l'éclairement relatif sous le peuplement et la densité apparente du sol ont été mesurées à l'aide d'un échantillonnage spatialement explicite. Une analyse des correspondances multiples (ACM) couplée à des géostatistiques a été utilisée pour caractériser la variabilité et l'hétérogénéité des formes d'humus ainsi que leur corrélation spatiale avec les caractéristiques de peuplement. La variabilité, l'hétérogénéité et l'activité des formes d'humus sont plus fortes sous peuplement mixte. Sous ce peuplement, l'amélioration de l'activité des formes d'humus est liée à la distribution spatiale des retombées de feuilles de charme. Ces résultats semblent indiquer que, pour un pourcentage donné d'une espèce ligneuse à litière améliorante, un mélange d'arbre par pied a un meilleur impact sur les formes d'humus qu'un mélange par bouquet.

forme d'humus / peuplement pur / peuplement mélangé / géostatistiques / patrons spatiaux / hétérogénéité / Fagus sylvatica / Carpinus betulus

\section{INTRODUCTION}

Humus form is defined as the group of organic and organicenriched mineral horizons at the soil surface $[33,55]$. Humus form descriptions are currently based on morphological properties. Moreover, in the French classification [1, 17], it is the entire macro-morphological features of the "épisolum humifère" (i.e. humic epipedon according to [55]), which defines humus forms consisting of the $\mathrm{O}$ and $\mathrm{A}$ horizons and their vertical sequence. The vertical organisation of these constitutive horizons is considered to be a great integrator of topsoil biological activity $[32,34]$, which conditions the rate of decomposition processes. Its importance for the productivity of terrestrial ecosystems, such as forests, has largely been recognized [33]. Thus, the development of silvicultural practices promoting topsoil mineralization has become a necessity for sustainable silviculture [49].
There are many factors influencing humus form characteristics, acting at various spatial and time scales such as topography [28], parent material [48] and stand dynamics [3, 10, 13, 47] at a coarse scale, and microbial communities [53] or root activity [45] at a fine scale. At stand level, canopy composition and structure may influence humus forms. Concerning the structure, the opening of canopy due to tree partial removal, leading to more light reaching the soil, is thought to increase organic matter decomposition [25] and thus to modify humus form characteristics. Tree species composition and the position of trees has also a strong influence on the organic layer properties $[12,43]$. The chemical composition of leaves differs considerably between tree species and affects litter decomposition rate and humus quality [44]. It has been recognized for a long time that the presence of mull-forming tree species within a stand dominated by moder or mor-forming species provides a

* Corresponding author: Michael.Aubert@univ-rouen.fr 
positive impact on organic layer properties [15, 20, 31, 46]. Although these studies underlined the better quality of humus form in the presence of mull-forming species, the spatial pattern of this improvement was not described. The question of the existence and strength of spatial correlations between stand composition and recorded variations in humus form properties remains. Is this improvement localised near mull-forming species or does it spread throughout the stand? Answering this question could provide practical background for forest managers on whether to mix tree species in a dispersed or clumped mixture.

In the present paper, we compare humus form variability and heterogeneity in a pure beech stand (Fagus sylvatica L.) and a mixed beech-hornbeam (Carpinus betulus L.) stand. Macromorphological humus form descriptors (including $\mathrm{pH}$ and organic $\mathrm{C}$ and $\mathrm{N}$ ) were recorded using a spatially explicit sample design at stand level. Variability, i.e. changes in the values of a given property [37], was assessed by multivariate analysis. Heterogeneity, i.e. spatial structure of variability [62], was quantified using geostatistics [28]. Moreover, three variables supposed to influence humus form features were recorded: leaf litter composition, light intensity accounting for stand management as well as bulk density for harvesting practices (soil compaction). The aim of this study was to test four hypotheses:

(1) Variability of humus form is greater under a mixed stand than under a pure stand,

(2) Humus form is on average more active under a mixed than under a pure stand,

(3) Humus form is more heterogeneous under a mixed canopy than under a pure one,

(4) The improving effect of hornbeam is limited to the hornbeam litterfall distribution rather than spreading throughout the stand.

\section{MATERIALS AND METHODS}

\subsection{Definition and nomenclature of humus forms}

According to [1], soil horizons containing organic matter can be divided in: (i) holorganic horizons (O horizons) almost without mineral material and (ii) organo-mineral horizon (A horizon) below. $\mathrm{O}$ horizons can be divided into three types according to the degree of litter transformation [34]:

- OL (Oi in USDA nomenclature) consisting of almost unmodified leaf and woody fragments. This horizon can be divided into: (i) OLn consisting of litter less than one year old without obvious decomposition; and (ii) OLv consisting of litter more than one year old with coloration changes, cohesion and hardness mainly due to fungal activity.

- OF (Oe in USDA nomenclature): consisting of a mixture of coarse plant fragments with fine organic matter (FOM) resulting from faecal pellets accumulation. Depending on the percentage of FOM, this horizon can de divided into OFr (less than $30 \%$ FOM) and OFm (30-70\% FOM). As earthworm activity is reduced, leaf transformation is attributed to the activity of soil epigeic fauna and fungi.

- OH (Oa in USDA nomenclature): more than 70\% FOM corresponding to accumulation of faecal pellets and fine plant fragments. It can be divided into $\mathrm{OHr}$ with 70 to $90 \% \mathrm{FOM}$ and $\mathrm{OHf}$ with 90 to $100 \%$.
Table I. Stands description. Percent of beech, hornbeam, sessile oak and holly represent the number of stems of these species as a percentage of the total number of stems. Values presented in parenthesis represent the standard error. Mean RI (Relative Irradiance) is the mean value of the 121-recorded measures on the sampling grid.

\begin{tabular}{lcc}
\hline & Pure stand & Mixed stand \\
\hline Age (years) & 116 & 114 \\
Last thinning operation & 1995 & 1998 \\
Number of tree $\left(\mathrm{ha}^{-1}\right)$ & 178 & 179 \\
DBH $(\mathrm{cm})$ & $41.7(17.8)$ & $40.94(13.62)$ \\
Basal area $\left(\mathrm{m}^{2} \cdot \mathrm{ha}^{-1}\right)$ & 28.71 & 26.14 \\
Percent of beech & $94.38 \%$ & $67.04 \%$ \\
Percent of hornbeam & $0 \%$ & $30.73 \%$ \\
Percent of sessile oak & $5.06 \%$ & $2.23 \%$ \\
Percent of holly & $0.56 \%$ & $0 \%$ \\
Mean RI & $5.18(0.78)$ & $4.77(0.61)$ \\
\hline
\end{tabular}

"Humus forms" is the macro-morphological description of the humic epipedon (the French "épisolum humifère") i.e. the vertical sequence of its constitutive horizons. It results from active processes in the different layers [18]. According to Brêthes [16], the main humus forms occurring in beech forest of Upper-Normandy located on very acidic and oligosaturated Luvisols are:

- Oligomull (usual horizon sequence: OL, (OF)/structured A);

- Dysmull (usual horizon sequence: OL, OF/structured A);

- Hemimoder (usual horizon sequence: OL, OF/unstructured A);

- Eumoder (usual horizon sequence: OL, OF, OH (thin)/unstructured A);

- Dysmoder (usual horizon sequence: OL, OF, OH (thick)/unstructured A).

Correspondence with Green et al. classification [33] is as follows: Oligomull $=$ Hemimor, Dysmull $=$ Leptomoder and Hemi-, Eu- and Dysmoder $=$ Leptomoder or Mormoder.

\subsection{Sites description}

The two stands are located in Upper-Normandy (northern France). The pure beech stand belongs to the state forest of Eawy $\left(01^{\circ} 18^{\prime} \mathrm{E}\right.$; $49^{\circ} 44^{\prime} \mathrm{N} ; 205 \mathrm{~m}$ a.s.1.). The mixed beech-hornbeam one is located in the state forest of Lyons ( $01^{\circ} 37^{\prime} \mathrm{E}$; $49^{\circ} 26^{\prime} \mathrm{N} ; 200 \mathrm{~m}$ a.s.l.). The mean annual rainfall and temperature are $800 \mathrm{~mm}$ and $10^{\circ} \mathrm{C}$ respectively.

Stand choice was guided so that differences in humus form variability and heterogeneity could be only due to stand characteristics (stand composition and organisation) and not to site differences (climate, soil and management). Thus, stands were chosen with the same vegetation succession stage i.e. a mature stand with a closed canopy [2] characterised by: (i) ecological similarity of plant communities and (ii) a low rate of litter incorporation [3]. According to phytosociological classifications, both belonged to the Endymio-Fagetum [7]. Trees were mapped and the breast height $(1.3 \mathrm{~m})$ diameters were measured within the area of the sampling design ( $1 \mathrm{ha}$ ). The similarity of stand structures was checked (see Tab. I). Both stands are situated in a topographically flat area. They were characterised by the same parent materials: more than $80 \mathrm{~cm}$ of loess (lamellated silts) resting on the same type of clay with flints $[38,39]$. Two soil profiles were described for each stand thanks to two pedological pits located at two opposite angles of the sampling grid. Physico-chemical analyses were performed on the horizons of one soil profile for each stand (see appendix). 
Table II. List of qualitative variables and their modalities used for humiferous episolum description.

\begin{tabular}{|c|c|c|c|}
\hline \multirow{2}{*}{$\begin{array}{l}\text { Variables } \\
\text { OLv state }\end{array}$} & \multicolumn{3}{|c|}{ Modalities } \\
\hline & 1) Absent & 2) Present - discontinuous & 3) Present - continuous \\
\hline OFr state & 1) Absent & 2) Present - discontinuous & 3) Present - continuous \\
\hline OFm state & 1) Absent & 2) Present - discontinuous & 3) Present - continuous \\
\hline OHr state & 1) Absent & 2) Present - discontinuous & 3) Present - continuous \\
\hline A state & 1) Absent & 2) Present - discontinuous & 3) Present - continuous \\
\hline OLn thickness* & 1) $0-1 \mathrm{~cm}$ & 2) $1-3 \mathrm{~cm}$ & 3) $3-6 \mathrm{~cm}$ \\
\hline OLv thickness* & 1) $0-0.5 \mathrm{~cm}$ & 2) $0.5-1.5 \mathrm{~cm}$ & 3) $1.5-3 \mathrm{~cm}$ \\
\hline OFr thickness* & 1) $0-0.5 \mathrm{~cm}$ & 2) $0.5-1.5 \mathrm{~cm}$ & 3) $1.5-2.5 \mathrm{~cm}$ \\
\hline OFm thickness* & 1) $0-0.5 \mathrm{~cm}$ & 2) $0.5-1.5 \mathrm{~cm}$ & 3) $1.5-3.5 \mathrm{~cm}$ \\
\hline \multirow[t]{2}{*}{ OHr thickness* } & 1) $0-0.2 \mathrm{~cm}$ & 2) $0.2-0.6 \mathrm{~cm}$ & 3) $0.6-1 \mathrm{~cm}$ \\
\hline & 4) $1-2.1 \mathrm{~cm}$ & & \\
\hline \multirow[t]{2}{*}{ A thickness* } & 1) $0-0.5 \mathrm{~cm}$ & 2) $0.5-1 \mathrm{~cm}$ & 3) $1-2 \mathrm{~cm}$ \\
\hline & 4) $2-6 \mathrm{~cm}$ & & \\
\hline $\mathrm{OHr} / \mathrm{A}$ transition & 1) Sharp & 2) Quite sharp & 3) Progressive \\
\hline A aggregate size & 1) $<2 \mathrm{~mm}$ & 2) $2-5 \mathrm{~mm}$ & \\
\hline \multirow[t]{2}{*}{ A structure rank } & 1) Without aggregate & 2) Slightly aggregated & 3) Moderately aggregated \\
\hline & 4) Strongly aggregated & & \\
\hline \multirow[t]{2}{*}{$\mathrm{A} / \mathrm{E}$ transition } & 1) $>8 \mathrm{~cm}$ & 2) $4-8 \mathrm{~cm}$ & 3) $2-4 \mathrm{~cm}$ \\
\hline & 4) $<2 \mathrm{~cm}$ & 5) Very sharp & \\
\hline $\mathrm{A} \mathrm{pH}_{\mathrm{H} 20} *$ & 1) $<3.6$ & 2) $3.6-4$ & 3) $>4$ \\
\hline A C-N ratio* & 1) $8-15$ & 2) $15-25$ & 3) $>25$ \\
\hline $5 \mathrm{~cm} \mathrm{pH}_{\mathrm{H} 20} *$ & 1) $3.5-4$ & 2) $4-5.5$ & \\
\hline $5 \mathrm{~cm}$ organic $\mathrm{C}^{*}$ & 1) $<2 \%$ & 2) $2-4 \%$ & 3) $>4 \%$ \\
\hline $5 \mathrm{~cm}$ total $\mathrm{N}^{*}$ & 1) $<0.05 \%$ & 2) $0.05-0.1 \%$ & 3) $>0.1 \%$ \\
\hline
\end{tabular}

* Indicates variables that were recorded as quantitative variables on the field and then converted into qualitative variables to perform the multiple correspondence analysis. Division into modalities was made from a close examination of information gathered from very large published expert knowledge [14, 17, 18, 32, 33, 34].

The studied stands had grown on a very acid, low redox, oligosaturated Luvisol according to the [1], equivalent to an endogleyic dystric Luvisol in the World Reference Base [29].

\subsection{Data collection}

For both stands, the spatial pattern of humus form was investigated using 121 points regularly distributed on a $10 \mathrm{~m}$-mesh square grid (100 $\times 100 \mathrm{~m}$ ) during winter 2000-2001. At each point, (i) 15 macro-morphological variables were recorded and (ii) A horizon and the five centimetres below, were sampled to estimate $\mathrm{pH}_{\mathrm{H} 2 \mathrm{O}}$, organic carbon and total nitrogen. $\mathrm{pH}_{\mathrm{H} 2 \mathrm{O}}$ was estimated according to Baize method [5] i.e. on a 1:2.5 soil/liquid mixture using distilled water. Organic $\mathrm{C}$ and total $\mathrm{N}$ were measured by gas chromatography with a $\mathrm{CHN}$ pyrolysis micro-analyser. The $\mathrm{C}-\mathrm{N}$ ratio was calculated for the A horizon. twenty variables were recorded at each point of the sample grid for both stands (Tab. II).

Three variables, which are likely to influence the spatial pattern of humus form, were also recorded at each point: (i) Leaf litter composition [44], (ii) light intensity below canopy [13] and (iii) the impact of harvesting methods on stand soil [6]. The OLn horizon was sampled in the field and leaves were hand sorted in the laboratory to assess the species composition of leaves expressed as percentage of OLn dry weight. The light intensity below the canopy was estimated in July 2001 at each grid node by the means of the relative irradiance (RI) at one metre above the soil, which is the light intensity under canopy/ light intensity outside the canopy, expressed as a percentage. The impact of harvesting methods was assessed by estimating soil compaction [40]. This was measured by the bulk density (BD) [5]. Soil cores $\left(100 \mathrm{~cm}^{3}\right)$ of the first $5 \mathrm{~cm}$ of the upper mineral soil were taken at each node and dried at $105^{\circ} \mathrm{C}$ for 3 days.

$$
\mathrm{BD}\left(\mathrm{g} \cdot \mathrm{cm}^{-3}\right)=\frac{\text { Core dry weight }}{\text { Core volume }}
$$

The presence near sampling points of tree trunks within $1.5 \mathrm{~m}$, of former windfalls, vehicle tracks, heaps of residual branches and stumps were also recorded.

\subsection{Statistical analysis}

To assess how humus form variability and heterogeneity is affected by the presence of hornbeam within a beech-dominated stand, multivariate and geostatistical analyses were used. First, a multiple correspondence analysis (MCA) was computed to (i) extract the main 
sources of variance in the data set and (ii) provide quantitative variables for geostatistical analysis. Secondarily, geostatistics (semi-variance analysis and the kriging procedure) were used to assess the spatial structure of humus forms and produce maps. Cross-variance analysis was performed between (i) sample scores along the main axes of the MCA and (ii) variables (leaf litter composition, light intensity, soil bulk density) supposed to influence humus forms and exhibiting structural variance. This was performed in order to account for spatial correlation between humus forms and these variables.

\subsubsection{Multiple correspondence analysis}

MCA can be considered as a normalized principal component analysis (PCA) for categorical data [58]. Study sites were analysed together in a data matrix of 242 records $\times 20$ variables (64 variable classes) (Tab. II). In order to help in interpreting MCA, the presence (near sampling points) of tree trunks, former windfalls, vehicle tracks, heaps of residual branches and stumps were projected as supplementary individuals in the subspaces defined by the main factors of variance underlined by the MCA.

A within inertia analysis was computed in order to extract the total variance for each site in the MCA. Within-class inertia represents the sum of the variance of each record forming a given class. Within a sample area, the greater the class variance is, the greater the spatial variability [62]. MCA and within-class inertia were computed with ADE software [59].

\subsubsection{Geostatistics}

Geostatistics were used to quantify spatial patterns of soil biotic or abiotic properties [28]. The method is based on the assumption that points situated closed to one other in space share more similarities than those farther apart [19]. In practice, geostatistical analysis is a twostep procedure [43]:

First, the spatial structure of a given variable is estimated using semi-variance analysis and described by a suitable model [52]. The semi-variance $\gamma$ for each specific distance interval $h$ is calculated by:

$$
\gamma(h)=\frac{1}{2 m(h)} \sum_{\mathrm{i}=1}^{m(h)}\left[Z\left(x_{\mathrm{i}}\right)-Z\left(x_{\mathrm{i}}+h\right)\right]^{2}
$$

where $m(h)$ is the number of data point pairs separated by a particular lag vector $\mathrm{h}$ (defined by both distance and direction); $Z\left(x_{\mathrm{i}}\right)$ the measured value of the variable $Z$ at point $x_{\mathrm{i}}$ and $Z\left(x_{\mathrm{i}}+h\right)$ the sampled value at a distance $h$ [61]. The graph plotting $\gamma$ and the distance between samples is called semi-variogram. Then, a theoretical model is fitted to the semi-variogram calculated from sampled values [51]. Two main model families exist: unbounded models where semi-variance appears to be infinite and bounded models (more common) where $\gamma$ reaches a maximum for a given lag distance [61]. In this case, the maximum semi-variance is called the "sill" and the distance at which the sill is reached, is called the "range". At lag 0, the intercept is called "nugget variance" $\left(C_{0}\right) . C_{0}$ may have two origins: measurement errors and variations at a smaller scale than that of the sampling design [52] i.e. $10 \mathrm{~m}$ in our study. The proportion of the total variance that can be attributed to the spatial autocorrelation is called the structural variance $(C)$ and is the difference between sill and nugget variance. $C /\left[C+C_{0}\right]$ ratio is used to assess indicative values of the structural variance [11, 42, 43]. When it reaches 1 , the whole sample variance is spatially dependent. When it approaches 0 , spatial dependence is low and factors accounting for nugget variance are preponderant. To evaluate the goodness of a model, a cross-validation procedure was used, which involves comparing kriged estimates and their variance [61]. The procedure is performed by removing each data point in the data set and using remaining data to predict it [36]. Three diagnostic statistics are calculated: (a) the mean error (ME) which should ideally be 0 ; (b) the mean squared error (MSE) which should approach 0 and (c) the mean squared deviation ratio (MSDR) which should be 1 .

$$
\begin{gathered}
M E=\frac{1}{N} \sum_{i=1}^{N}\left[Z\left(x_{\mathrm{i}}\right)-\bar{Z}\left(x_{\mathrm{i}}\right)\right] \\
M S E=\frac{1}{N} \sum_{i=1}^{N}\left[Z\left(x_{\mathrm{i}}\right)-\bar{Z}\left(x_{\mathrm{i}}\right)\right]^{2} \\
M S D R=\frac{1}{N} \sum_{i=1}^{N} \frac{\left[Z\left(x_{\mathrm{i}}\right)-\bar{Z}\left(x_{\mathrm{i}}\right)\right]^{2}}{\bar{\alpha}^{2}\left(x_{\mathrm{i}}\right)}
\end{gathered}
$$

where $\bar{\alpha}^{2}\left(x_{\mathrm{i}}\right)$ is kriging variance, $Z\left(x_{\mathrm{i}}\right)$ is the observed value and $\bar{Z}\left(x_{\mathrm{i}}\right)$ is the predicted value from cross-validation [36, 61].

The second step of a geostatistical analysis is the kriging procedure. The aim of kriging is to estimate values of a given variable at unsampled points using semi-variogram parameters $[19,28]$. In this study, we used ordinary kriging, which estimates the value $Z$ of a variable at a point $x_{0}$ using the formulae:

$$
Z\left(x_{0}\right)=\sum_{i=1}^{n} \lambda_{\mathrm{i}} Z\left(x_{\mathrm{i}}\right)
$$

where $\lambda_{\mathrm{i}}$ is a weight applied to each of the i neighbouring samples $Z\left(x_{\mathrm{i}}\right)$ [61]. $\lambda_{\mathrm{i}}$ are derived from a set of equations determined by the variogram model parameters [51].

A cross semi-variance analysis was used to assess the spatial correlation between two variables. This could reasonably be performed between two variables exhibiting almost the same autocorrelation range [61]. Two variables are cross-correlated when the values of one at given places are correlated with the values of the other variable [51]. Spatial interdependence between two variables $u$ and $v$ is estimated by the cross semi-variance $\bar{\gamma}_{\text {uv }}(h)$ :

$$
\gamma=\frac{1}{2 m(h)} \sum_{\mathrm{i}=1}^{m(h)}\left[z_{\mathrm{u}}\left(x_{\mathrm{i}}\right)-z_{\mathrm{u}}\left(x_{\mathrm{i}}\right)\right]\left[z_{\mathrm{v}}\left(x_{\mathrm{i}}\right)-z_{\mathrm{v}}\left(x_{\mathrm{i}}+h\right)\right]
$$

where $m(h)$ is the number of pairs of data points separated by a particular lag vector $h, z\left(x_{\mathrm{i}}\right)$ the measured value of the variable $Z$ at point $x_{\mathrm{i}}$ and $z\left(x_{\mathrm{i}}+h\right)$ the sampled value at a distance $\mathrm{h}$. The graph plotting the cross semi-variance against the distance $h$ is called the cross-variogram. Cross semi-variance is positive when the two variables are positively correlated and negative in the opposite case. The cross semi-variogram shows the same features as the semi-variogram [52].

Geostatistical analyses were performed on MCA record scores (three first axes), stand characteristics (percent of hornbeam litter in OLn and relative irradiance) and bulk density of soil (characteristic of harvesting impact). Prior to this, a normality test was performed on the variables using Statistix software [56]. If necessary, logarithmic transformation was applied. Geostatistical analyses were performed using Arcinfo 8.1, module Arcview, Geostatistical Analyst extension [27].

\section{RESULTS}

\subsection{Variability}

The total inertia of the performed MCA was 2.08. The first three axes explained $18 \%$ of the total variance observed in qualitative variables accounting for humus forms description (Fig. 1). 


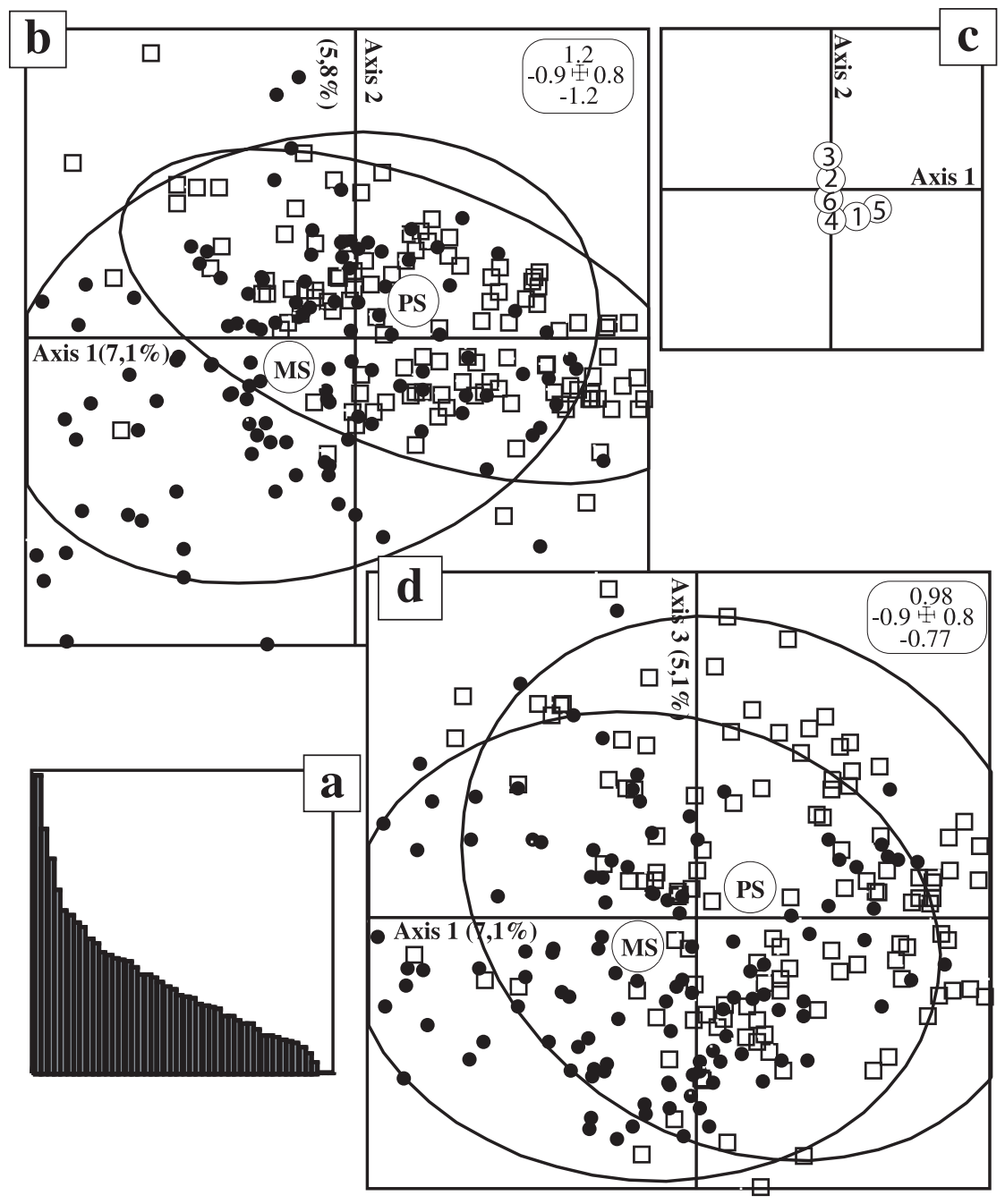

Figure 1. Results of the Multiple Correspondence Analysis (MCA): (a) eigenvalues diagram; (b) sample ordination in the plan defined by axes 1 and 2 of the MCA; pure beech stand samples are shown by white squares and mixed stand ones by black points; for pure and mixed stands, the centres of gravity of ellipsoids are equal to the mean of the sample coordinates; PS = pure beech stand; MS = mixed beech-hornbeam stand; (c) projection as supplementary variables on the factorial plan 1-2 of the proximity of tree trunks to the sampling points (1), ancient windfalls (2) vehicle tracks (3), heaps of residual branches (4), stumps (5) and without any special feature (6); (d) ordination of the samples in the plan defined by axes 1 and 3 .

Sample clouds on the ordination diagram were represented by ellipsoids containing $95 \%$ of points. The mixed stand (MS) ellipsoid was more elongated on axes 1 and 2 than that of the pure stand (PS). It was the opposite on axis 3. This indicated that the range of sample variability within stands was greatest for the mixed stand on axes 1 and 2 and for the pure stand on axis 3. This is confirmed on the whole of MCA by the within inertia analysis. The sum of the variance was 1.88 for PS records and 2.18 for MS ones.

For each axis, only the most explicative variables were represented in the modalities ordination diagram of variable classes (Fig. 2) depending on their correlation ratio (Tab. III). Axis 1 of the MCA accounted for $7.1 \%$ of the total inertia. The ordination of variable classes distinguished between (i) samples characterised by a thick and continuous OFr and a thick A horizon which was either strongly aggregated or not (negative part of axis); and (ii) samples with a thick and continuous $\mathrm{OHr}$ and a thin A horizon with weak aggregate size (positive part of the axis). This axis clearly opposed dysmull and hemimoder in the negative part from eumoder and dysmoder humus forms in the positive part. According to the coordinates of the centre of gravity of the ellipsoid on axis 1 , the mixed stand tended towards the more active humus forms while the pure stand tended toward the less active ones (Fig. 1).

Axis 2 accounted for $5.8 \%$ of the total inertia. It separated samples characterised by: (i) thick OL and OF horizons, a low $\mathrm{pH}_{\mathrm{H} 20}$ at $5 \mathrm{~cm}$ and a high percentage of organic carbon at $5 \mathrm{~cm}$ (negative part); from (ii) samples with a thin OL and OF, a high $\mathrm{pH}_{\mathrm{H} 20}$ at $5 \mathrm{~cm}$ and low percentage of organic carbon at $5 \mathrm{~cm}$ (positive part). The first category was mainly composed of samples recorded near tree trunks, stump or heaps of residual branches and the second one of samples recorded near vehicle 


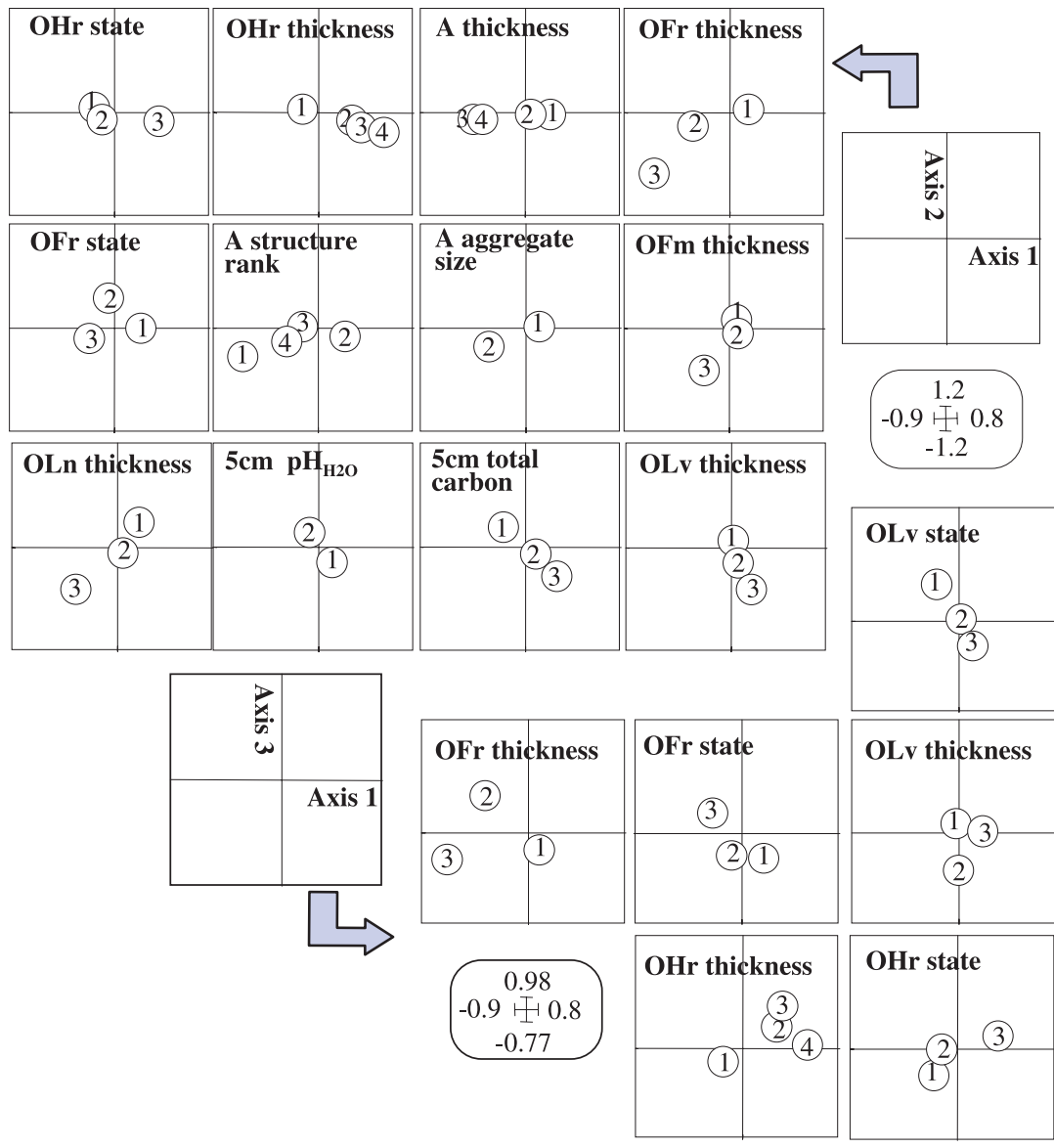

Figure 2. Ordination of variable classes (Tab. I) of qualitative variables accounting for humus form description; only the variables exhibiting the highest correlation ratios with the three first MCA axes are represented (see Tab. III).
Table III. Correlation coefficients between qualitative variables and the first third axes of the MCA.

\begin{tabular}{lccc}
\hline Variables & r axis 1 & r axis 2 & r axis 3 \\
\hline OLv state & 6 & 18.1 & 37.6 \\
OFr state & 30.5 & 11 & 32 \\
OFm state. & 2.1 & 13.1 & 14.5 \\
OHr state. & 42.1 & 4.9 & 18.4 \\
A state & 3.5 & 1.5 & 2 \\
OLn thickness & 13.2 & 35 & 1.3 \\
OLv thickness & 0.7 & 18.8 & 32.1 \\
OFr thickness & 35.4 & 20.5 & 31 \\
OFm thickness & 4.4 & 24.2 & 0.4 \\
OHr thickness & 41.7 & 7.5 & 22.3 \\
A thickness & 39.4 & 0.6 & 3.2 \\
OHr/A tr. & 8.2 & 1.3 & 0.7 \\
A aggregate size. & 18.7 & 6.8 & 4.7 \\
A structure rank. & 20 & 3.3 & 2.9 \\
A/E transition & 3.5 & 11.2 & 2.3 \\
A pH H2O & 3.1 & 14.6 & 4.8 \\
A C-N ratio & 0.4 & 0.2 & 0.4 \\
5 cm pH & 6.4 & 23.2 & 0.6 \\
5 cm organic C & 11.3 & 19.2 & 1.7 \\
5 cm total N & 5.5 & 8.6 & 1.6 \\
\hline
\end{tabular}

tracks (see Fig. 1c). The macro-morphological characteristics expressed the accumulation of organic matter (negative part) and topsoil disturbances by harvesting practices (positive part).

Axis 3 accounted for $5.1 \%$ of the total inertia. It distinguished between: (i) samples with a thick and continuous OLv, a discontinuous but thick $\mathrm{OFr}$ and an absent $\mathrm{OHr}$ (negative part); and (ii) samples characterised by an absent OLv, a continuous but moderately thick OFr and a thick and continuous $\mathrm{OHr}$. This was interpreted as contrasting between humus forms with a preponderant fungi activity and those in which soil arthropod activity dominates.

\subsection{Heterogeneity}

Semi-variance analysis performed on MCA sample scores and explicative variables showed that there was a great range of variation in the degree of spatial dependence. The three diagnostics of cross-validation (Tab. IV) validated the semi-variogram models for all variables except relative irradiance in mixed stands (MSE = 16.605 and MSDR = 1.669).

The proportion of variance accounted for by the spatial structure (Tab. IV) of humus form was on the whole low (ranging from 0 to $21.93 \%$ of total variance) except for MS scores on axis $1(43.19 \%)$. The great resulting nugget effect indicated that some spatial pattern might occur at smaller scale than that of the sampling design. Nevertheless, MS scores on axis 1 had 
Table IV. Semi-variogram model parameters for MCA samples scores and stand characteristics.

\begin{tabular}{ccccccccccc}
\hline Stands & Variables & Model & $\begin{array}{c}\text { Nugget } \\
(\mathrm{C} 0)\end{array}$ & $\begin{array}{c}\text { Sill } \\
(\mathrm{C}+\mathrm{C} 0)\end{array}$ & $\begin{array}{c}\mathrm{C} / \mathrm{C}+\mathrm{C} 0 \\
(\times 100)\end{array}$ & $\begin{array}{c}\text { Range } \\
(\mathrm{m})\end{array}$ & Neighbourhood & ME & MSE & MSDR \\
\hline Pure & Score axis 1 & Exp & 0.107 & 0.12 & 10.83 & 90.77 & 20 & 0.004 & 0.142 & 1.067 \\
& Score axis 2 & Sph & 0.075 & 0.085 & 11.76 & 22.14 & 5 & -0.003 & 0.09 & 0.991 \\
& Score axis 3 & Exp & 0.115 & 0.115 & 0 & & 20 & -0.006 & 0.117 & 0.997 \\
& RI & Sph & 31.242 & 49.494 & 36.85 & 49.62 & 20 & 0.016 & 0.106 & 0.998 \\
& BD & Exp & 0.006 & 0.009 & 24.44 & 32.16 & 8 & 0.001 & 0.011 & 0.997 \\
& & & & & & & & \\
Mixed & Score axis 1 & Exp & 0.081 & 0.141 & 43.19 & 69.64 & 20 & 0.004 & 0.113 & 1.004 \\
& Score axis 2 & Exp & 0.121 & 0.155 & 21.93 & 65.88 & 20 & 0.004 & 0.142 & 0.992 \\
& Score axis 3 & Exp & 0.079 & 0.087 & 8.04 & 76.64 & 20 & -0.007 & 0.087 & 1.016 \\
& RI & Exp & 0.408 & 0.572 & 28.67 & 65.88 & 20 & -0.078 & 16.605 & 1.669 \\
& BD & Exp & 0.00834 & 0.00863 & 3.36 & 88.60 & 20 & 0.001 & 0.011 & 1.008 \\
& \%HL & Sph & 0.041 & 0.282 & 85.46 & 65.62 & 20 & 0.00008 & 0.088 & 1.002 \\
\hline
\end{tabular}

Exp model: Exponential model; Sph model: Spherical model; RI: Relative irradiance; BD: Bulk density; \%HL: Percent of hornbeam litter in OLn; ME: Cross validation Mean Error; MSE: Cross validation mean squared error; MDSR: Cross validation mean squared deviation ratio.

a greater structural variance than that of PS. The score autocorrelation ranges were respectively 69.5 for MS and 91 for PS. Kriging maps (Figs. 3 and 4) illustrated the stronger patchiness of MS on axis 1 than that of PS.

With the exception of bulk density within MS, explicative variables showed a higher structural variance than humus form. Nevertheless, except for the percentage of hornbeam litter (HL) within MS ( $85.46 \%$ of structural variance), there was a large nugget effect. The HL autocorrelation range was about $65.5 \mathrm{~m}$. $\mathrm{HL}$ and MS scores on axis 1 were the variables exhibiting the greatest structural variance. Moreover, their autocorrelation ranges were very similar. Cross-semivariance analysis between them revealed a negative co-regionalization for a distance of less than $64 \mathrm{~m}$ (Fig. 5). The cross-validation procedure validated the fitted model. This meant that eumoder and dysmoder humus forms were spatially correlated with a low percentage of hornbeam litter in the OLn horizon. Cross-semivariance analysis was performed between all other variables for each stand but the resulting cross-semivariograms did not provide significant results.

\section{DISCUSSION}

\subsection{Humus forms variability}

In the slightly desaturated loamy soil context of the Northwestern France, multiple correspondence analysis interpretation showed that humus forms occurring within both stands ranged from dysmull to dysmoder i.e. belonged to low-activity humus forms [35]. The range of variation in humus forms was greater under the mixed stand than under the pure one. This result is in accordance with the first hypothesis. The presence of hornbeam within the mixed stand seems to turn humus forms toward the dysmull pole. This result supports hypothesis 2 , that humus form is more active in the mixed than in the pure stand.
This higher decomposition rate is beneficial for nutrient availability, tree growth and long-term site productivity [49, 60]. Nevertheless, Bernier [9] reported that humus profiles sampled in comparable spruce stands in terms of tree age, showed only slight functional differences. Moreover in coniferous forests in the French Alps, Michalet et al. [41] found a discrepancy between the very low biological activity of dysmull and its status as mull in the French morphological classification [17]. Thus, as our differences between pure and mixed stands are based on a macro-morphological description of humus forms, they do not allow us to make any conclusions on functional differences. The better quality of humus form within the mixed stand may be the consequence of (i) the faster disappearance of hornbeam leaves (due to their better quality than beech leaves) and/or (ii) a greater biological activity under the mixed stand than under the pure stand. The preponderant fungi activity under the mixed stand (interpretation of MCA axis 3) tends to confirm the second explanation. Nevertheless, further investigations should be performed to search for a relation of cause and effect between hornbeam litter quality and biological activity. According to Toutain [60], in the absence of anecic earthworms (which is the case for the studied sites [4]), white rot fungi are the primary metabolizers of leaf brown pigments and their rapid degradation may account for the formation of mull.

Tree trunks are recognized as having a strong influence on humus form resulting in (i) an increase of organic layer thickness and (ii) a decrease of $\mathrm{A}$ horizon $\mathrm{pH}[8,23]$. With regard to the ordination of "stumps" within the factorial plan 1-2 of the MCA, this influence seems to endure after tree felling. Heaps of residual branches also represent a factor of organic matter accumulation. Nevertheless, regarding its ordination along the MCA axis 1 (Fig. 1c), this factor does not seem to turn humus forms toward the dysmoder pole like the proximity of tree trunk. Vehicle tracks, removing litter and exposing the mineral horizons also have a strong influence on humus forms characteristics $[6,22]$. By revealing all these factors as second 

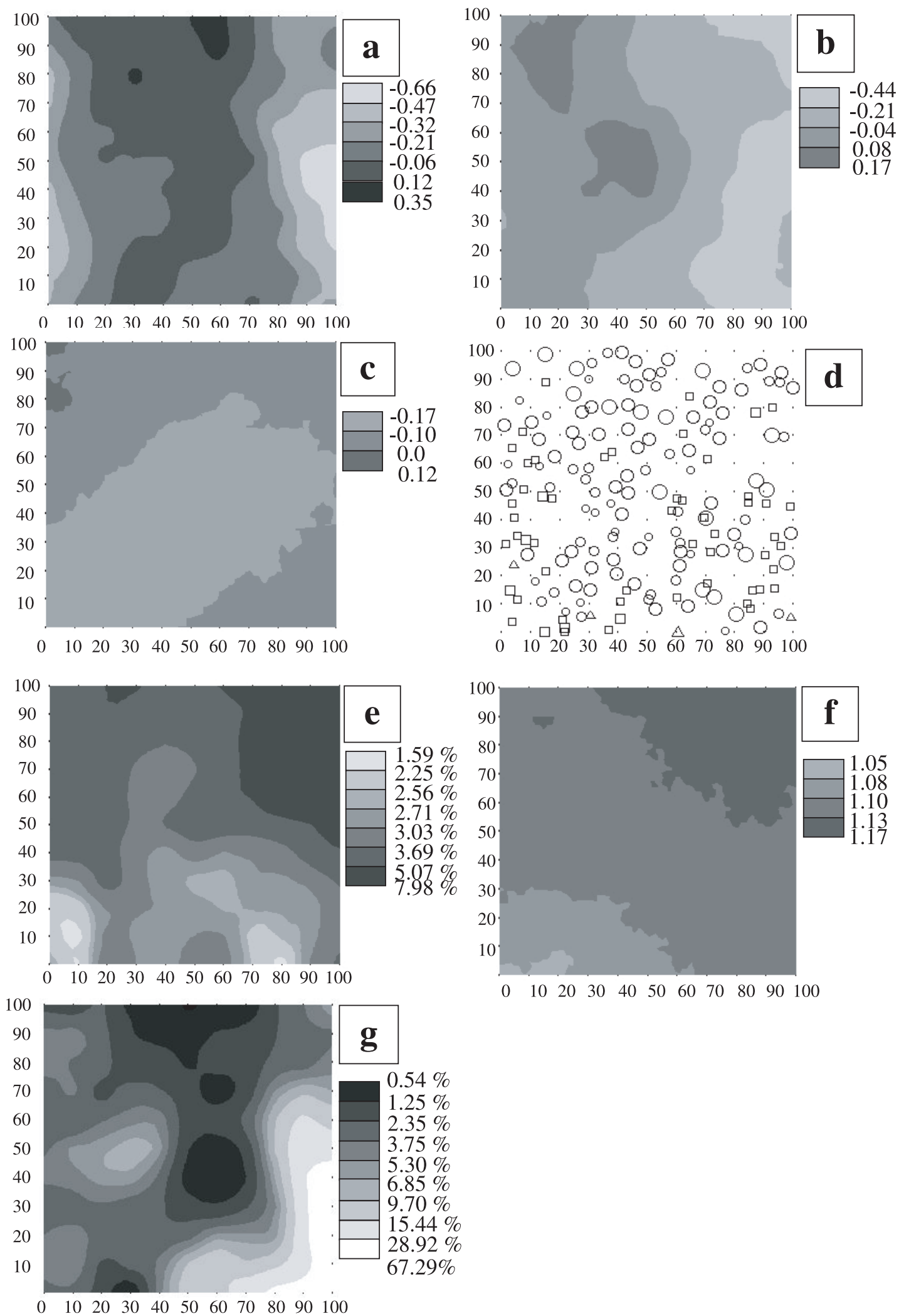

Figure 3. Kriged maps of mixed beech-hornbeam stand: (a) MCA sample scores on axis 1; (b) sample scores on axis 2; (c) sample scores on axis 3; (d) stand map; circles = beech; squares = hornbeam; triangles = oak; the size of circles, squares and triangles is proportional to trunks diameter; (e) kriged map of relative irradiance; (f) kriged map of bulk density and (g) kriged map of the percent of hornbeam litter in OLn. 

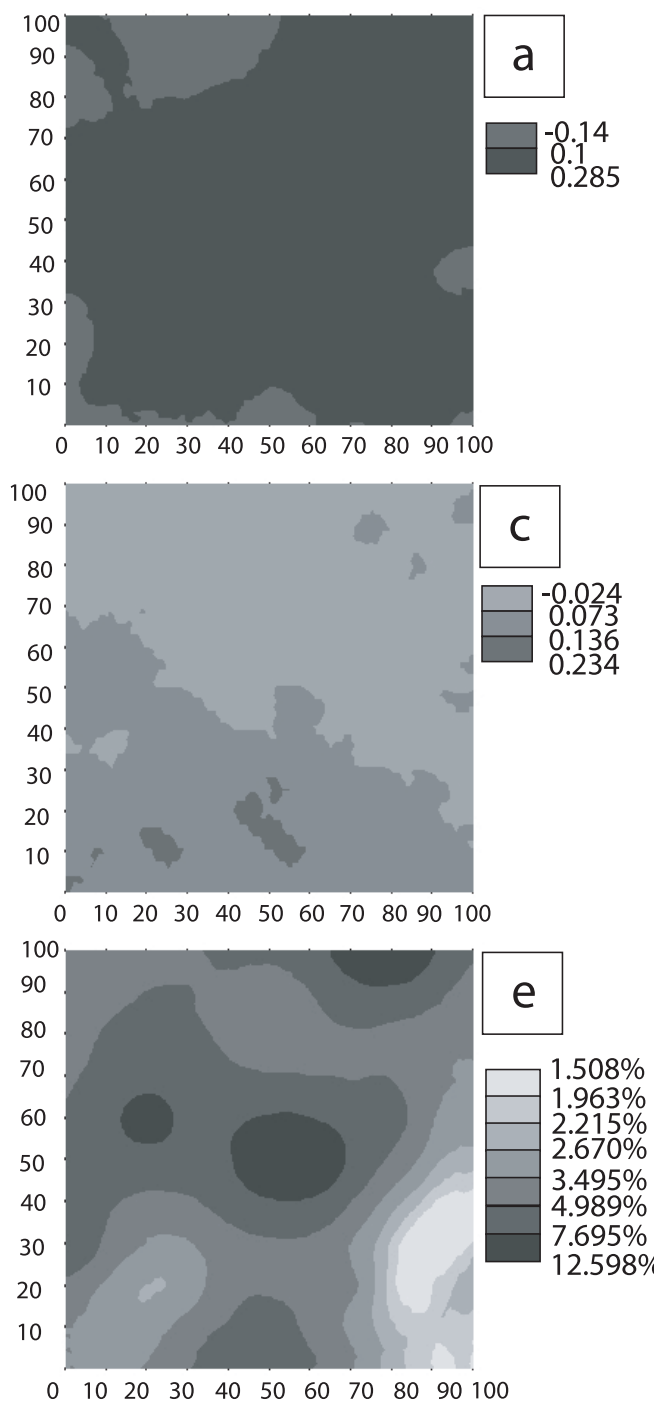
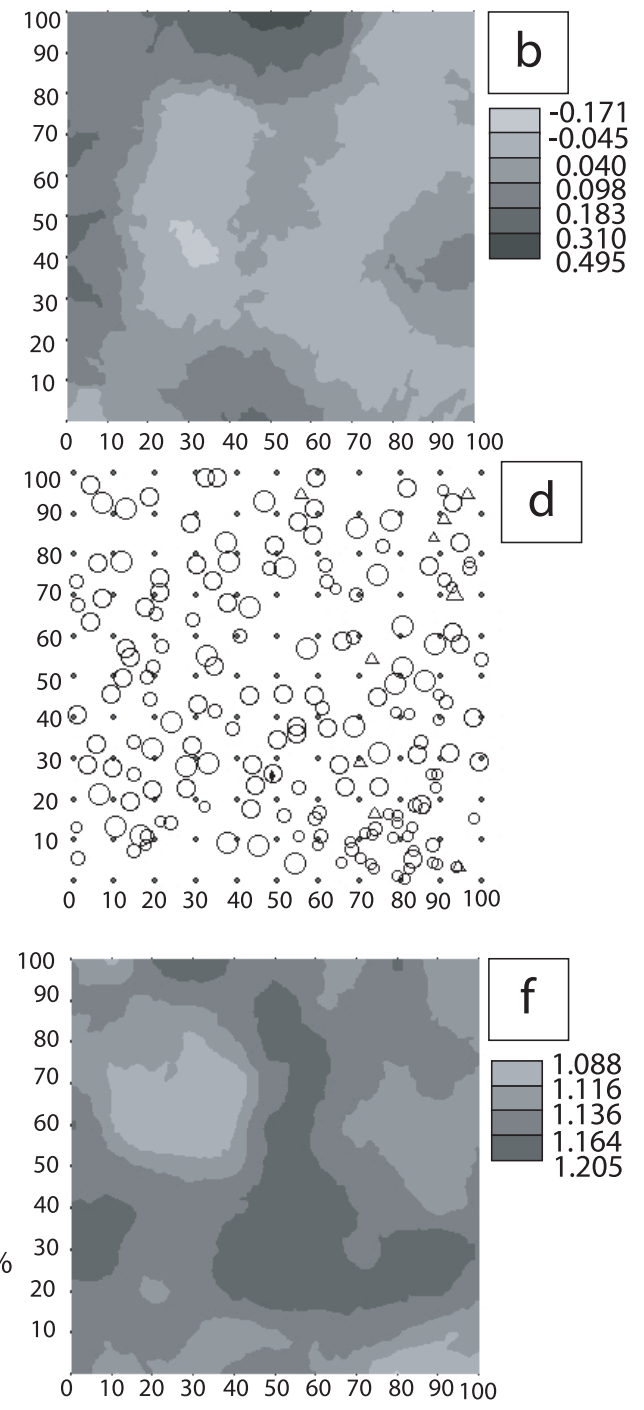

Figure 4. Kriged maps of pure beech stand: (a) MCA sample scores on axis 1 ; (b) samples scores on axis 2; (c) samples scores on axis 3 ; (d) stand map; circles $=$ beech; triangles $=$ oak; lozenge $=$ holly; the size of circles, triangles and lozenge is proportional to trunks diameter; (e) kriged map of relative irradiance; (f) kriged map of bulk density.

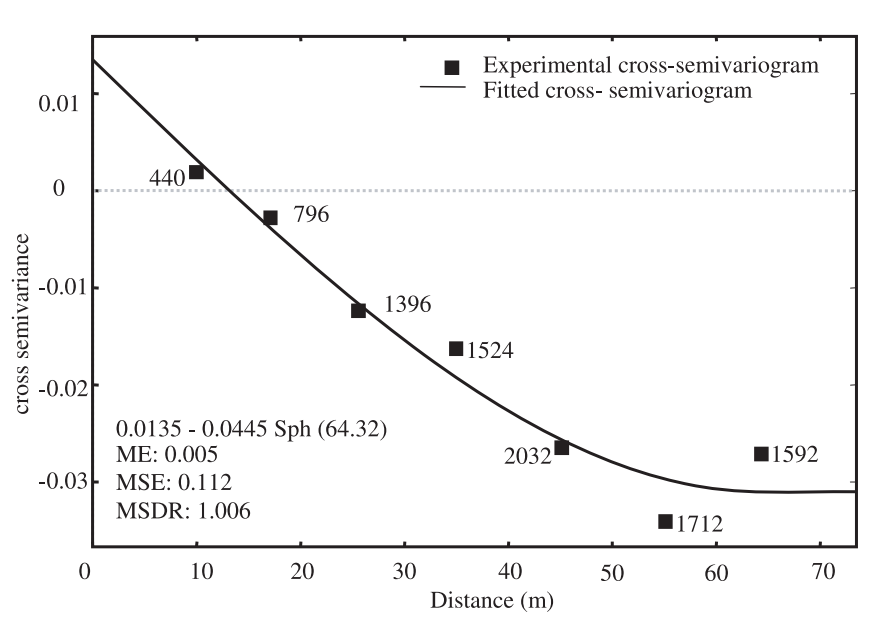

Figure 5. Cross-semivariogram for mixed beech-hornbeam samples scores on MCA axis 1 and the percent of hornbeam litter in OLn. Distance unit (in $\mathrm{m}$ ) is the inter-sample distance $(10 \mathrm{~m})$. order determinants, MCA indicates that, at stand level, harvesting practices have a strong impact on humus form.

\subsection{Humus form spatial patterns}

The aim of the study was to determine the influence of the canopy composition patchiness on humus form. Geostatistical analysis performed at our scale of investigation revealed that the heterogeneity of humus forms, i.e. spatial structure of variability [62], is greater under the mixed stand than under the pure one. As stand choice was guided so that differences in humus form heterogeneity could be only due to stand characteristics, this result supports our hypothesis 3 .

Geostatistics performed at stand level revealed a strong nugget effect for most variables except MS scores on axis 1 and the percentage of hornbeam leaves in OLn. This suggests that spatial variations occurred at a distance smaller than our sampling interval. In the forest ecosystems of British Columbia, Qian and Klinka [50] reported that the spatial pattern of humus 
forms occurred in polygons with lateral dimension ranging from 1 to $7 \mathrm{~m}$. Saetre and Baath [53] found that the spatial pattern of microbial communities in mixed spruce-birch stand varied between 1 and $11 \mathrm{~m}$. Möttönen et al. [43] showed that fungal biomass under Scots pine forest exhibited an autocorrelation range greater than $4 \mathrm{~m}$. Thus, spatial patterns of decomposition processes and those of decomposer organisms occur at a fine scale within stands. This is in accordance with MCA results i.e. the distinction between fungi and arthropod activity was revealed as a third order determinant in our sampling design.

Growing mixtures of tree species might promote humus decomposition or prevent its accumulation [49]. From a practical viewpoint, can the forester manage decomposition processes simply by managing tree stand composition? A considerable number of tree mixture types exist [54], including a vertical mixture (several strata) or horizontal mixture (clumps of trees of different sizes, dispersed mixture, even-aged stand or uneven-aged stands). Their impacts on humic epipedon functioning could thus differ greatly depending on (i) whether edaphic and/or climatic local conditions are favourable for a great biological activity or not (bordering but not extreme in our case) or (ii) whether leaves are mixed on the floor or not [57]. Ferrari [30] has emphasized the influence of the withinstand pattern of litterfall on mineralization processes. Our results showed that less active humus forms are spatially correlated with the lowest percentage of hornbeam litter in OLn. They suggest that the impacts of hornbeam do not diffuse into beechdominated areas but are confined to its litterfall area. This supports hypothesis 4 . We assume that with an equivalent percentage of mull-forming tree species, a dispersed tree mixture provides a more extensive improvement than a clumped mixture.

\section{CONCLUSION}

The study provides empirical evidence that (i) the variability and heterogeneity of humus form are correlated with the spatial pattern of stand canopy, (ii) humus forms are more active within mixed stand and (iii) the improvement of decomposition processes is limited to spatial pattern of hornbeam litterfall. Our approach based on the macro-morphological description of humus forms appears to be a practical tool for assessing the impact of stand management. Nevertheless, relationships between humus form and "épisolum humifère" functioning are still poorly understood. More investigations (nutrient cycling and soil fauna characterisation) should be performed within both stands and different types of mixture, to determine the impact of mixed beech-hornbeam litter on humus form functioning.

Acknowledgements: The authors would like to acknowledge the "Conseil regional de Haute-Normandie" for M. Aubert's research grant and the French "Office national des forêts" for site selection. We also thank Mickaël Hedde and Julien Fiquepron for their help in data recording and, an anonymous reviewer for useful comments.

\section{REFERENCES}

[1] AFES, A sound reference base for soils, INRA, Paris, 1998.

[2] Aubert M., Alard D., Bureau F., Diversity of plant assemblages in managed temperate forests: a case study in Normandy (France), For. Ecol. Manage. 175 (2003) 321-337.
[3] Aubert M., Bureau F., Alard D., Bardat J., Effect of tree mixture on the humic epipedon and vegetation diversity in managed beech forest (Normandy, France), Can. J. For. Res. 34 (2004) 233-248.

[4] Aubert M., Hedde M., Decaëns T., Bureau F., Margerie P., Alard D., Effects of tree composition on earthworms and other macroinvertebrates in beech forests of Upper Normandy (France), Pedobiologia 47 (2003) 904-612.

[5] Baize B., Guide des analyses en pédologie, INRA Editions, Paris, 2000.

[6] Ballard T.M., Impacts of forest management on northern forest soils, For. Ecol. Manage. 133 (2000) 37-42.

[7] Bardat J., Phytosociologie et écologie des forêts de Haute-Normandie : leur place dans le contexte sylvatique ouest-européen, Bull. Soc. Bot. Centre-Ouest (1993) 376.

[8] Beniamino F., Ponge J.-F., Arpin P., Soil acidification under the crown of oak trees: I. Spatial distribution, For. Ecol. Manage. 40 (1991) 221-232.

[9] Bernier N., Fonctionnement biologique des humus et dynamique des pessières alpines. Le cas de la forêt de Macot-La-Plagne (Savoie), Ecologie 28 (1997) 23-44.

[10] Bernier N., Ponge J.-F., Humus form dynamics during the sylvogenetic cycle in a mountain spruce forest, Soil. Biol. Biochem. 26 (1994) 183-220.

[11] Boerner R.E.J., Scherzer A.J., Brinkman J.A., Spatial patterns of inorganic $\mathrm{N}, \mathrm{P}$ availability, and organic $\mathrm{C}$ in relation to soil disturbance: a chronosequence analysis, Appl. Soil Ecol. 7 (1998) 159177.

[12] Boettcher S.E., Kalisz P.J., Single-tree influence on soil properties in the mountains of eastern Kentucky, Ecology 71 (1990) 13651372.

[13] Bonneau M., Evolution of the mineral fertility of an acidic soil during a period on ten years in the Vosges mountains (France). Impact of humus mineralisation, Ann. For. Sci. 62 (2005) 253-260.

[14] Bonneau M., Souchier B., Pédologie. Tome 1 - Constituants et propriétés du sol, Masson, Paris, 1994.

[15] Brandtberg P.-O., Lundkvist H., Bengtsson J., Changes in forestfloor chemistry caused by birch admixture in Norway spruce stands, For. Ecol. Manage. 130 (2000) 253-264.

[16] Brêthes A., Catalogue des stations forestières du nord de la HauteNormandie, Office national des forêts, Paris, 1984.

[17] Brêthes A., Brun J.J., Jabiol B., Ponge J.F., Toutain F., Classification of forest humus forms: a French proposal, Ann. Sci. For. 52 (1995) 535-546.

[18] Brêthes A., Brun J.-J., Jabiol B., Ponge J.-F., Toutain F., Souchier B., Bouché M.B., Types of humus form in temperate forests, in: AFES (Eds.), A sound reference base for soils, INRA, Paris, 1998, pp. 266-282.

[19] Bringmark E., Bringmark L., Improved soil monitoring by use of spatial pattern, Ambio 27 (1998) 45-52.

[20] Brown A.H.F., Functioning of mixed-species stands at Gisburn, N.W. England, in: Cannell M.G.R., Malcolm D.C., Robertson P.A. (Eds.), The ecology of mixed-species stands of trees, Blackwelll Scientific Publications, 1992, pp. 125-150.

[21] Ciesielski H., Sterckeman T., Determination of cation exchange capacity and exchangeable cations in soil by means of cobalt hexamine trichloride. Effects of experimental conditions, Agronomie 17 (1997) 1-7.

[22] Deconchat M., Effets des techniques d'exploitation forestière sur l'état de surface du sol, Ann. For. Sci. 58 (2001) 653-661.

[23] Deschaseaux A., Ponge J.-F., Changes in the composition of humus profiles near the trunk base of an oak tree (Quercus petraea (Mattus.) Liebl.), Eur. J. Soil. Biol. 37 (2001) 9-16.

[24] Dyer B., On the analytical determination of probably available "mineral" plant food in soils, J. Chem. Soc. 65 (1894) 115-167.

[25] Epron D., Ngao J., Granier A., Interannual variation of soil respiration in a beech forest ecosystem over a six-year study, Ann. For. Sci. 61 (2004) 499-505.

[26] Espiau P., Peyronel A., L'acidité d'échange dans les sols. Méthode de détermination de l'aluminium échangeable et des protons échangeables, Sci. Sol 3 (1976) 161-175. 
[27] ESRI, ArcGIS - Geostatistical analyst, ESRI, New-York, 2001.

[28] Ettema C.H., Wardle D.A., Spatial soil ecology, Tree 17 (2002) $177-183$.

[29] FAO, World reference bases for soil resources, Rome, 1998.

[30] Ferrari J.B., Fine scale patterns of leaf litterfall and nitrogen cycling in an old-growth forest, Can. J. For. Res. 29 (1999) 291-302.

[31] Garay I., Étude d'un écosystème forestier mixte: II. Les sols, Rev. Ecol. Biol. Sol. 17 (1980) 525-541.

[32] Gobat J.-M., Aragno M., Matthey W., Le sol vivant, Presses Polytechniques et Universitaires Romandes, Lausanne, 1998.

[33] Green R.N., Trowbridge R.L., Klinka K., Towards a taxonomic classification of humus forms, For. Sci. Monogr. 29 (1993) 1-46.

[34] Jabiol B., Brêthes A., Ponge J.-F., Toutain F., Brun J.-J., L'humus sous toutes ses formes, ENGREF, Nancy, 1995.

[35] Jabiol B., Höltermann A., Gégout J.-C., Ponge J.-F., Brêthes A., Typologie des formes d'humus peu actives, Etude Gestion Sols 7 (2000) 133-154.

[36] Johnston K., Ver Hoef J.M., Krivoruchko K., Lucas N., Using ArcGIS Geostatistical analyst, ESRI, New York, 2001.

[37] Kolasa J., Rollo C.D., Introduction: the heterogeneity of heterogeneity, a glossary, in: Kolassa J., Pickett S.T.A. (Eds.), Ecological heterogeneity, Springer-Verlag, New York, 1991, pp. 1-23.

[38] Laignel B., Quesnel F., Lecoustumier M.-N., Meyer R., Variability of the clay fraction of the clay with flints of the western part of the Paris Basin, C. R. Acad. Sci. Paris 326 (1998) 467-472.

[39] Lautridou J.-P., Le cycle périglaciaire pléistocène en Europe du Nord-Ouest et plus particulièrement en Normandie, Thesis, University of Caen, Caen, 1985.

[40] McMahon S., A survey method for assessing sites disturbance, New Zealand Logging Industry, Rotorua, 1995, $54 \mathrm{p}$.

[41] Michalet R., Gandoy C., Cadel G., Girard G., Grossi J., Joud D., Pache G., Humus functioning types in evergreen coniferous forests of the French Inner Alps., C. R. Acad. Sci. Paris Sci. Vie 324 (2001) 59-70.

[42] Morris S.J., Spatial distribution of fungal and bacterial biomass in southern Ohio hardwood forest soils: fine scale variability and microscale patterns, Soil. Biol. Biochem. 31 (1999) 1375-1386.

[43] Möttönen M., Jarvinen E., Hokkanen T.J., Kuuluvainen T., Ohtonen R., Spatial distribution of soil ergosterol in the organic layer of a mature Scots pine (Pinus sylvestris L.) forest, Soil. Biol. Biochem. 31 (1999) 503-516.

[44] Muys B., The influence of tree species on humus quality and nutrient availability on a regional scale (Flanders, Belgium), in: Nilsson L.O., Hüttl R.F., Johansson U.T. (Eds.), Nutrient uptake and cycling in forest ecosystems, Kluwer Academic Publishers, Netherlands, 1995, pp. 649-660.

[45] Neirynck J., Mirtcheva S., Sioen G., Lust N., Impact of Tilia platyphyllos Scop., Fraxinus excelsior L., Acer pseudoplatanus L., Quercus robur L., and Fagus sylvatica L. on earthworm biomass and physico-chemical properties of loamy topsoil, For. Ecol. Manage. 133 (2000) 275-286.

[46] Ponge J.-F., Prat B., Les collemboles, indicateurs du mode d'humification dans les peuplements résineux, feuillus et mélangés: résultats obtenus en forêt d'Orléans, Rev. Ecol. Biol. Sol. 19 (1982) 237-250.

[47] Ponge J.-F., Delhaye L., The heterogeneity of humus profiles and earthworm communities in a virgin beech forest, Biol. Fertil. Soils 20 (1995) 20-24.

[48] Ponge J.-F., Ferdy J., Growth of Fagus sylvatica in an old-growth forest as affected by soil and light conditions, J. Veg. Sci. 8 (1997) 789-796.

[49] Prescott C.E., Maynard D.G., Laiho R., Humus in northern forests: friend or foe? For. Ecol. Manage. 133 (2000) 23-36.

[50] Qian H., Klinka K., Spatial variability of humus forms in some coastal forest ecosystems of British Columbia, Ann. For. Sci. 52 (1995) 653-666.

[51] Rossi J.-P., Delaville L., Quénéhervé P., Microspatial structure of plant-parasitic nematode community in a sugarcane field in Martinique, Appl. Soil Ecol. 3 (1996) 17-26.

[52] Rossi J.P., Lavelle P., Ebagnerin-Tondoh J., Statistical tool for soil biology X. Geostatistical analysis, Eur. J. Soil. Biol. 31 (1995) 1-9.

[53] Saetre P., Baath E., Spatial variation and patterns of soil microbial community structure in a mixed spruce-birch stand, Soil. Biol. Biochem. 32 (2000) 909-917.

[54] Schütz J.-P., Sylviculture 2 : la gestion des forêts irrégulières et mélangées, Presses Polytechniques et Universitaires Romandes, Lausanne, 1997.

[55] SSAJ, Glossary of soil science terms, Soil Science Society of America, Madison, USA, 1997.

[56] Statistix, Analytical Software, Analytical Software Publisher, Tallahassee, 1998.

[57] Sulkava P., Huhta V., Habitat patchiness affects decomposition and faunal diversity: a microcosm experiment on forest floor, Oecologia 116 (1998) 390-396.

[58] Tenenhaus M., Young F.W., An analysis and synthesis of multiple correspondence analysis, optimal scaling, dual scaling, homogeneity analysis and other methods for quantifying categorical multivariate data, Psychometrika 50 (1985) 91-119.

[59] Thioulouse J., Chessel D., Doledec S., Olivier J.M., ADE-4: a multivariate analysis and graphical display software, Stat. Comput. 7 (1997) 75-83.

[60] Toutain F., Activité biologique des sols, modalité et lithodépendance, Biol. Fertil. Soils 3 (1987) 31-38.

[61] Webster R., Oliver M.A., Geostatistics for environmental scientists, John Wiley \& Sons, England, 2001.

[62] Wiens J.A., Ecological heterogeneity: an ontogeny of concepts and approaches, in: Hutchings M.J., John E.A., Stewart A.J. (Eds.), Ecological consequences of environmental heterogeneity, Blackwell Science, Oxford, 2000, pp. 8-30. 
Appendix. Major properties of soil profiles performed on the pure beech and mixed beech-hornbeam stands.

\begin{tabular}{|c|c|c|c|c|c|c|c|c|c|c|c|c|c|}
\hline \multirow{3}{*}{ Profile } & \multirow{3}{*}{ Horizon } & \multirow[b]{2}{*}{ Depth } & \multicolumn{5}{|c|}{ Particle size distribution } & \multirow{3}{*}{$\begin{array}{c}\mathrm{pH} \\
\mathrm{H}_{2} 0^{\dagger}\end{array}$} & \multirow{3}{*}{$\mathrm{pH} \mathrm{KCl}{ }^{\dagger}$} & \multirow{3}{*}{$\Delta \mathrm{pH}^{\dagger}$} & \multirow{3}{*}{\multicolumn{2}{|c|}{$K_{0}-1$}} & \multirow{3}{*}{$\mathrm{C} / \mathrm{N}$} \\
\hline & & & $\begin{array}{c}\text { Coarse } \\
\text { sand }\end{array}$ & Fine sand & Coarse silt & Fine silt & Clay & & & & & & \\
\hline & & $\mathrm{cm}$ & \multicolumn{5}{|c|}{---------------------------\%\%-------------------------- } & & & & & & \\
\hline \multirow{6}{*}{ Pure stand } & A & $0-2.5$ & ND & ND & ND & ND & ND & 4.00 & ND & ND & 140.73 & 8.73 & 16.12 \\
\hline & E1 & $2.5-7$ & 1.20 & 15.60 & 43.20 & 26.70 & 13.30 & 4.30 & 3.70 & 0.60 & 14.62 & 0.78 & 18.74 \\
\hline & E2 & $7-40$ & 1 & 16.6 & 42.9 & 26.00 & 13.50 & 4.40 & 4.00 & 0.40 & 6.44 & 0.44 & 14.64 \\
\hline & Btg1 & $40-100$ & 1.20 & 14.30 & 38.90 & 26.00 & 19.6 & 4.30 & 3.90 & 0.40 & 2.14 & 0.29 & 7.38 \\
\hline & $\mathrm{Btg} 2$ & $100-120$ & 2.00 & 12.90 & 38.60 & 21.20 & 25.30 & 5.00 & 3.90 & 1.10 & 1.5 & 0.26 & 5.77 \\
\hline & IIc & & 2.90 & 10.30 & 39.00 & 22.80 & 25.00 & 5.20 & 4.10 & 1.10 & 1.6 & 0.3 & 5.33 \\
\hline \multirow{7}{*}{ Mixed stand } & A & $0-2$ & ND & ND & ND & ND & ND & 3.80 & ND & ND & 98.92 & 6.08 & 16.27 \\
\hline & E1 & $2-10$ & 0.70 & 8.40 & 41.70 & 34.90 & 14.30 & 4.10 & 3.50 & 0.60 & 28.25 & 1.46 & 19.35 \\
\hline & E2 & $10-45$ & 0.90 & 8.70 & 46.60 & 30.00 & 13.80 & 4.40 & 4.00 & 0.40 & 6.72 & 0.45 & 14.93 \\
\hline & Btg1 & $45-60$ & 0.80 & 9.50 & 42.40 & 32.10 & 15.20 & 4.40 & 4.00 & 0.40 & 2.55 & 0.35 & 7.29 \\
\hline & $\mathrm{Btg} 2$ & $60-120$ & 0.70 & 8.10 & 37.50 & 29.30 & 24.40 & 4.90 & 3.90 & 1.00 & 1.68 & 0.27 & 6.22 \\
\hline & $\mathrm{Btg} 3$ & $120-140$ & 12.00 & 7.60 & 31.60 & 22.10 & 26.70 & 5.20 & 4.10 & 1.10 & 1.95 & 0.31 & 6.29 \\
\hline & IIc & & 3.00 & 4.30 & 16.90 & 13.70 & 62.10 & 5.20 & 4.20 & 1.00 & 2.94 & 0.51 & 5.57 \\
\hline
\end{tabular}

Exchange complex (Cobaltihexammine) $)^{\S}$

\begin{tabular}{|c|c|c|c|c|c|c|c|c|c|c|c|c|c|c|}
\hline \multirow[t]{2}{*}{ Profile } & Horizon & $\mathrm{K}$ & $\mathrm{Ca}$ & $\mathrm{Mg}$ & $\mathrm{Na}$ & $\mathrm{Al}$ & Mn & $\mathrm{H}^{+}$ & $\mathrm{S}^{\#}$ & $\mathrm{~T}^{\dagger \dagger}$ & $\mathrm{BS}+\dagger$ & $\mathrm{P} 2 \mathrm{O} 5_{\mathrm{Dy}} \S \S$ & $\mathrm{P} 2 \mathrm{O} 5_{\mathrm{Du}} \# \#$ & $\mathrm{Al}_{(\mathrm{KCl})}{ }^{\dagger \dagger \dagger}$ \\
\hline & \multicolumn{13}{|c|}{ 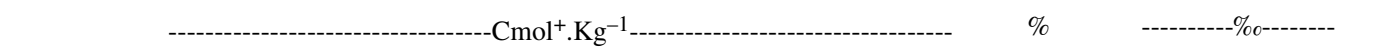 } & $\mathrm{Cmol}^{+} \cdot \mathrm{Kg}^{-1}$ \\
\hline \multirow{6}{*}{ Pure stand } & A & 0.40 & 1.67 & 0.56 & 0.09 & 4.66 & 0.43 & 1.52 & 2.72 & 9.50 & 28.63 & 0.08 & 0.27 & ND \\
\hline & E1 & 0.07 & 0.08 & 0.05 & 0.03 & 3.54 & 0.09 & 0.34 & 0.23 & 3.60 & 6.39 & 0.03 & 0.11 & 3.76 \\
\hline & E2 & 0.04 & 0.05 & 0.03 & 0.02 & 2.68 & 0.05 & 0.16 & 0.14 & 2.80 & 5.00 & 0.02 & 0.17 & 3.1 \\
\hline & Btg1 & 0.11 & 0.08 & 0.06 & 0.03 & 5.16 & 0.06 & 0.17 & 0.28 & 6.00 & 4.67 & 0.01 & 0.15 & 5.19 \\
\hline & Btg2 & 0.18 & 2.78 & 2.43 & 0.09 & 2.65 & 0.06 & 0.21 & 5.48 & 9.30 & 58.92 & 0.02 & 0.23 & 2.79 \\
\hline & IIc & 0.12 & 3.18 & 2.11 & 0.08 & 1.14 & 0.05 & 0.20 & 5.49 & 8.20 & 66.95 & 0.01 & 0.08 & 1.27 \\
\hline \multirow{7}{*}{ Mixed stand } & A & 0.36 & 1.57 & 0.43 & 0.04 & 3.95 & 0.242 & 1.74 & 2.4 & 7.80 & 30.77 & 0.06 & 0.20 & ND \\
\hline & E1 & 0.12 & 0.30 & 0.09 & 0.02 & 4.22 & 0.053 & 0.44 & 0.53 & 5.30 & 10.00 & 0.02 & 0.10 & 4.79 \\
\hline & $\mathrm{E} 2$ & 0.06 & 0.07 & 0.03 & 0.02 & 2.4 & 0.082 & 0.18 & 0.18 & 2.60 & 6.92 & 0.04 & 0.15 & 2.81 \\
\hline & Btg1 & 0.07 & 0.10 & 0.04 & 0.02 & 3.00 & 0.192 & 0.21 & 0.23 & 3.30 & 6.97 & 0.05 & 0.30 & 3.1 \\
\hline & Btg2 & 0.23 & 3.02 & 2.46 & 0.05 & 3.23 & 0.068 & 0.19 & 5.76 & 10.20 & 56.47 & 0.01 & 0.22 & 3.4 \\
\hline & Btg3 & 0.15 & 4.81 & 2.35 & 0.08 & 0.88 & 0.217 & 0.15 & 7.39 & 9.50 & 77.79 & 0.02 & 0.40 & 0.94 \\
\hline & IIc & 0.21 & 11.33 & 3.26 & 0.15 & 1.00 & 0.077 & 0.30 & 14.95 & 18.60 & 80.38 & 0.01 & 0.26 & 1.04 \\
\hline
\end{tabular}

$\dagger \mathrm{pH}_{\mathrm{H} 2 \mathrm{O}}$ and $\mathrm{pH}_{\mathrm{KCl}}$ estimated according to Baize method [6]: 1:2.5 soil/liquid mixture with distilled water and $\mathrm{KCl}(1 \mathrm{M})$. $\mathrm{pH}=\mathrm{pH}$

$\ddagger$ Total carbon and total nitrogen were measured by the mean of gaseous chromatography method with pyrolysis micro-analyser "CHN".

$\S$ Determination of exchange complex by the mean of cobalt hexamine trichloride [21].

\# $\mathrm{S}=(\mathrm{K}, \mathrm{Ca}, \mathrm{Mg}, \mathrm{Na})$.

$\dagger^{\dagger} \mathrm{T}=$ cation exchange capacity $=\left(\mathrm{K}, \mathrm{Ca}, \mathrm{Mg}, \mathrm{Na}, \mathrm{Mn}, \mathrm{Al}, \mathrm{H}^{+}\right)$.

$\$ \mathrm{BS}=$ Base saturation $=\mathrm{S} / \mathrm{T} \times 100$.

$\S \S$ Determination of phosphorus soluble with Dyer method [24]

\# \# Determination of phosphorus soluble with Duchaufour-Bonneau method in [14].

$+\dagger \dagger$ Determination of Exchangeable aluminium with Espiau-Peyronel method [26]. 